\title{
PERAN PENGGUNAAN ANGGARAN DALAM PERUSAHAAN YANG MENGALAMI PERUBAHAN STRATEGIS
}

\author{
Oleh : Andwiani Sinarasri, SE, M.Si
}

\author{
Fakultas Ekonomi \\ Universitas Muhammadiyah Semarang
}

\begin{abstract}
Abstrak:
Organisasi yang berada dalam ketidakpastian lingkungan yang tinggi mendorong mereka untuk lebih ekstensif menggunakan sistem pengendalian strategik yang bertujuan untuk mempertahankan integrasi strategi. Simons (1987) menggambarkan bahwa interactive controls digunakan karena adanya ketidakpastian strategi dan mendukung manajemen untuk mengawasi timbulnya ancaman dan kesempatan.

Sistem pengendalian akuntansi manajemen (termasuk proses penganggaran) memfasilitasi adaptasi terhadap faktor eksternalitas dengan cara memediasi antara ancaman dan kesempatan eksternal dengan organizational functioning (strategi atau struktur). Oleh karena itu, perusahaan diharapkan secara proaktif memformulasikan, merumuskan dan menyesuaikan strategi pasar sesuai dengan kondisi lingkungan (ancaman dan kesempatan). Hal ini diperkuat oleh Porter (1980) yang berpendapat bahwa perusahaan harus menyelaraskan strategi bisnis dengan kondisi lingkungan.

Anggaran merupakan karakteristik utama sistem pengendalian akuntansi manajemen yang digunakan oleh manajemen sebagai sarana pengkoordiniran dan penyampaian prioritas-prioritas strategis, dan bersama-sama dengan sistem penghargaan, seringkali digunakan untuk memperkuat komitmen manajemen tingkat bawah terhadap prioritas-prioritas tersebut.
\end{abstract}

Kata Kunci : Anggaran, perubahan strategi, kinerja perusahaan 


\section{PENDAHULUAN}

Persaingan merupakan suatu hal yang dapat menjadi inti kesuksesan ataupun menjadi penyebab kegagalan sebuah perusahaan, karena persaingan dapat memberikan arah bagi perusahaan dalam menentukan aktivitas yang tepat untuk dilaksanakan. Langkah-langkah strategik sangat dibutuhkan pada saat persaingan semakin ketat dan terjadi ketidakpastian lingkungan yang tinggi.

Kondisi yang menuntut perusahaan untuk menempuh langkahlangkah strategik dalam menuju ke masa depan adalah terjadinya krisis ekonomi. Kondisi krisis ditandai dengan kondisi ketidakpastian lingkungan yang tinggi dan turbulence (Govindarajan, 1984). Mulyadi (2000) berpendapat bahwa untuk keluar dari krisis ekonomi, perusahaan harus mendesain, memasang dan mengoperasikan sistem perumusan strategi, sistem perencanaan strategik dan sistem penyusunan program untuk memotivasi seluruh personel perusahaan dalam mencari dan merumuskan langkah-langkah strategik untuk membangun masa depan perusahaan mereka.

Sistem pengendalian akuntansi manajemen (termasuk proses penganggaran) memfasilitasi adaptasi terhadap faktor eksternalitas dengan cara memediasi antara ancaman dan kesempatan eksternal dengan organizational functioning (strategi atau struktur). Oleh karena itu, perusahaan diharapkan secara proaktif memformulasikan, merumuskan dan menyesuaikan strategi pasar sesuai dengan kondisi lingkungan (ancaman dan kesempatan). Hal ini diperkuat oleh Porter (1980) yang berpendapat bahwa perusahaan harus menyelaraskan strategi bisnis dengan kondisi lingkungan.

Organisasi yang berada dalam ketidakpastian lingkungan yang tinggi mendorong mereka untuk lebih ekstensif menggunakan sistem pengendalian strategik yang bertujuan untuk mempertahankan integrasi strategi. Simons (1987) menggambarkan bahwa interactive controls digunakan karena adanya ketidakpastian strategi dan mendukung manajemen untuk mengawasi timbulnya ancaman dan kesempatan.

Dalam literatur manajemen, perubahan strategis seringkali dianggap sinonim dengan perubahan organisasional. Salah satu tema yang dominan dalam literatur tersebut adalah bahwa perusahaan beradaptasi terhadap perubahan-perubahan kondisi lingkungan (Astley dan Van de Ven, 1983; Singh et al., 1986). Penelitianpenelitian tersebut lebih banyak menitikberatkan pada mekanismemekanisme dan proses-proses yang menunjang adaptasi strategis terhadap perubahan kondisi lingkungan. Sementara itu, penelitian lain lebih menitikberatkan perubahan strategi pada muatan dan proses perubahan strategis itu sendiri. Muatan perubahan strategis adalah sasaran, jangkauan dan prioritas kompetitif yang ditentukan oleh manajemen pusat. Sedangkan proses perubahan strategis mencerminkan pendekatan yang dipilih perusahaan untuk mengatur 
perumusan dan penerapan strategi (Ginsberg, 1988).

Dalam beberapa penelitian sebelumnya dinyatakan bahwa sistem pengendalian yang digunakan dalam organisasi berpengaruh secara signifikan terhadap peningkatan kinerja organisasi (Gul, 1991; Mia, 1993; Mia dan Chenhall, 1994; Gul dan Chia, 1994). Hubungan tersebut tidak secara langsung demikian, tetapi terdapat faktor kontekstual dalam hubungan sistem pengendalian organisasi dan kinerja organisasi. Semakin fit hubungan sistem pengendalian dengan faktor kontekstual, semakin tinggi kinerja yang dicapai sebuah organisasi. Peneliti lainnya yaitu Simons (1987), menguji perbedaan sistem pengendalian akuntansi pada perusahaan-perusahaan yang menjalankan bisnis dengan memakai strategi yang berbeda, yaitu strategi defender dan prospector. Hasil penelitian Simons memperlihatkan bahwa kesesuaian antara mekanisme sistem pengendalian akuntansi dengan strategi unit bisnis menghasilkan kinerja yang lebih tinggi. Selanjutnya dinyatakan bahwa perusahaan yang mencapai keunggulan kompetitif dengan strategi tertentu harus didukung oleh sistem pengendalian akuntansi dengan karakteristik tertentu. Sehingga sistem pengendalian akuntansi antara perusahaan yang menerapkan strategi defender mempunyai karakteristik yang berbeda dengan strategi prospector.

Teori kontinjensi, yang selama ini mendominasi studi perilaku organisasi, rancangan sistem pengendalian, strategi dan kinerja organisasi, menyatakan bahwa kinerja organisasi merupakan konsekuensi fit atau kesesuaian antara dua atau lebih faktor-faktor (Van de Ven dan Drazin, 1985). Berbagai faktor ini adalah faktor eksternal (lingkungan), faktor tipologi struktur organisasi, faktor rancangan sistem pengendalian, faktor teknologi, yang akhirnya semua akan bermuara pada kinerja organisasi. Sedangkan Fisher (1998), yang meneliti hubungan antara teori kontinjensi dan sistem pengendalian manajemen, menyatakan bahwa menurut teori kontinjensi, desain dan penggunaan sistem pengendalian tergantung pada konteks setting organisasi. Pasangan (match) yang lebih baik antara sistem pengendalian dengan variabel kontinjensi dihipotesiskan menghasilkan kinerja organisasi yang meningkat. Riset tersebut menyimpulkan pentingnya sistem pengendalian akuntansi manajemen dalam pencapaian strategi yang ditetapkan oleh manajemen.

Simons (1990) menawarkan satu penjelasan untuk ketidakkonsistenan dalam literatur ini. Menurutnya penelitian-penelitian tersebut terlalu condong untuk menyelidiki seberapa besar prioritasprioritas strategis yang berbeda mempengaruhi peran penting sistem pengendalian akuntansi manajemen sebagai pengevaluasi kinerja, atau yang disebut sebagai peran diagnostik (Simons, 1990; 1991). Sebaliknya, tidak banyak penelitian yang diarahkan untuk menyelidiki bagaimana peran akuntansi dapat berubah tergantung pada seting strategisnya (Chapman, 
1997). Mungkin saja ketergantungan pada bentuk-bentuk pengendalian akuntansi tidak akan menghilangkan peran pentingnya dalam kondisikondisi strategis yang berbeda, tetapi fungsi atau manfaatnya yang akan berubah. Khususnya, sesuatu yang selama ini terabaikan dalam penelitianpenelitian adalah potensi sistem pengendalian akuntansi manajemen untuk digunakan lebih aktif sebagai sarana perumusan dan penerapan perubahan-perubahan ke arah strategis, atau yang disebut oleh Simons (1994) sebagai kegunaan interaktif sistem pengendalian akuntansi manajemen.

\section{PERMASALAHAN}

Dari penjelasan yang telah dikemukakan dalam pendahuluan diatas, maka permasalahan yang mungkin timbul adalah bagaimana peran anggaran dalam perusahaan yang mengalami perubahan strategis ?

\section{PEMBAHASAN \\ Perubahan Strategis}

Miles dan Snow (1978)
menjelaskan definisi dikemukakan oleh Chandler, strategi adalah penentuan dasar sasaran dan tujuan jangka panjang perusahaan, adopsi rangkaian tindakan, serta alokasi sumber daya kunci, untuk mencapai sasaran. Strategi menurut Porter (1980), harus dirumuskan secara eksplisit agar kebijakankebijakan fungsional dapat mengkoordinasi dan mengarahkan departemen-departemen ke pencapaian tujuan dan misi perusahaan. Strategi dapat dipandang dari tiga sudut: (1) perumusan strategi, (2) implementasi strategi, yaitu penerapan strategi tersebut ke dalam tindakan nyata, dan (3) pengendalian strategik, yaitu perubahan strategi atau implementasinya untuk menjamin bahwa hasil yang diharapkan dapat dicapai. Pada dasarnya strategi dipilih untuk meraih peluang utama yang tersembunyi dimasa depan dan untuk memecahkan masalah utama yang dihadapi oleh perusahaan (Mulyadi, 2000).

Strategi bisnis merupakan rencana terpadu tentang uraian produk, kegiatan, fungsi dan pasar yang saat ini dijalankan perusahaan untuk mencapai tujuan utama perusahaan. Strategi bisnis disusun berdasarkan keunggulan perusahaan dalam menghadapi tantangan lingkungan. Strategi bersaing dimaksudkan melakukan sesuatu yang berbeda dengan para pesaing dalam industri yang sama. Perbedaan dapat didasarkan pada produk, delivery system, pendekatan pemasaran, dan lain-lain (Porter, 1985).

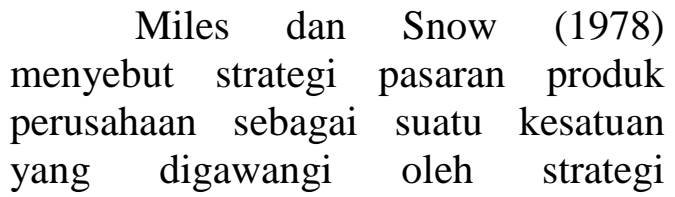
'defender' (mempertahankan kepemimpinan pasar dengan kisaran jasa dan produk yang relatif stabil dan terbatas) di satu sisi dan strategi 'prospector' (perubahan-perubahan dan respon-respon cepat terhadap peluang-peluang baru pasar) di sisi yang lain. Pemilihan strategi didasarkan pada adaptive cycle, yaitu berdasarkan siklus adaptasi lingkungan. Oleh karena itu, strategi organisasional yang dipilih oleh 
perusahaan dapat berubah sesuai dengan perubahan lingkungan. Maka strategi yang dipilih perusahaan merupakan "on going process".

Prospector dan defender adalah dua jenis tipe strategi organisasi yang berada pada dua titik ekstrim. Karakter dan strateginya sangat bertolak belakang. Simons (1990) mengidentikkan kedua tipe organisasi tersebut dengan model strategi persaingan yang diklasifikasi oleh Porter (1980), yaitu strategi defferentiation dan cost leadership, dan Mintzberg (1973) dengan entrepreneurial dan adaptive. Kemudian Miller dan Friesen (1982) dengan entrepreneurial dan concervative. Sedangkan Govindarajan dan Gupta (1985) mengklasifikasi strategi menjadi build dan harvest. Selanjutnya Ittner dan Larcker (1997b) berpendapat bahwa organisasi prospector untuk perusahaan yang menerapkan differentiation, dan organisasi defender untuk perusahaan yang menerapkan strategi cost leadership. Demikian juga dengan perusahaan yang menerapkan strategi build untuk organisasi prospector dan strategi harvest untuk organisasi defender. Jadi intinya organisasi prospector, strategi differentiation dan entrepreneurial memiliki ciri atau karakteristik yang sama, begitu juga dengan organisasi defender, cost leadership dan konservatif (Suryani, 2001).

Dalam literatur manajemen yang lain, perubahan strategis seringkali dianggap sinonim dengan perubahan organisasional. Literatur tersebut menitikberatkan perubahan strategis pada muatan dan proses perubahan strategis. Muatan perubahan strategis adalah sasaran, jangkauan dan prioritas kompetitif yang ditentukan oleh manajemen pusat; sedangkan proses perubahan strategis adalah pendekatan yang dipilih perusahaan untuk mengatur perumusan dan penerapan strategi (Ginsberg 1988). Penelitian yang dilakukan oleh Kelly dan Amburgey (1991); Wiersema dan Bantel (1992); Greiner dan Bhambri (1989); serta Abernethy dan Brownell (1999) lebih menitikberatkan perubahan strategis pada hal-hal yang berkaitan dengan proses terjadinya perubahan, siapa yang memulainya, apa saja hambatannya, dan mekanisme apa yang digunakan untuk menunjangnya

Sedangkan menurut Shortell et al. (1990), perubahan strategis adalah tingkat pergeseran perusahaan di sepanjang jalur defender-prospector. Misalnya, perusahaan bisa saja bergerak dari posisi strategis yang menitikberatkan pada kisaran produk yang terbatas ke posisi yang lebih berorientasi pasar, dimana prioritas strategisnya dititikberatkan untuk mengembangkan diversifikasi produk guna memenuhi kebutuhan-kebutuhan pasar. Jadi, menurut Abernethy dan Brownell (1999), perubahan strategis dapat berkisar dari tidak ada perubahan sama sekali hingga perubahan strategis tingkat tinggi.

Penggunaan Anggaran

$\begin{array}{lr}\text { Anggaran } & \text { merupakan } \\ \text { karakteristik utama } & \text { sistem } \\ \text { pengendalian akuntansi } & \text { manajemen } \\ \text { dan digunakan oleh manajemen } & \text { man dan } \\ \text { sebagai sarana pengkoordiniran da }\end{array}$


penyampaian prioritas-prioritas strategis, dan bersama-sama dengan sistem penghargaan, seringkali digunakan untuk memperkuat komitmen manajemen tingkat bawah terhadap prioritas-prioritas tersebut.

Pengertian anggaran menurut Lowe (1970), anggaran merupakan pernyataan mengenai apa yang diharapkan, direncanakan atau diperkirakan terjadi dalam periode tertentu yang direncanakan dimasa yang akan datang. Sedangkan Anthony dan Reece (1989), mengemukakan bahwa anggaran adalah suatu rencana yang rinci, yang dinyatakan secara formal dalam ukuran kuantitatif, biasanya dalam satuan uang yang menunjukkan sumber dan penggunaan daya suatu organisasi dalam jangka waktu tertentu, biasanya satu tahun.

Dalam beberapa penelitian akuntansi manajemen, selalu berasumsi bahwa anggaran berfungsi sebagai 'peran diagnostik' (Simons, 1990), atau berperan sebagai 'mesin penjawab' (Burchell et al., 1980). Dalam perannya ini, anggaran berfungsi sebagai pengevaluasi kinerja dan menghubungkan suatu hasil dengan fungsi atau anggota organisasi tertentu.

Di sisi lain, anggaran juga dapat digunakan sebagai mesin dialog, pembelajaran dan penciptaan ide (Burchell et al., 1980). Anggaran selain sebagai alat perencanaan dan pengendalian, juga berfungsi untuk mengkoordinasikan,

mengkomunikasikan, memotivasi dan mengevaluasi prestasi (Kennis, 1979). Disamping sebagai alat memotivasi kinerja para manajer tingkat bawah, juga bermanfaat dalam memudahkan perencanaan (Chow, et al., 1988). Dalam memotivasi bawahan dapat dilakukan dengan memberi penghargaan berupa bonus, insentif tambahan, pujian maupun hadiah. Motivasi ini tidak hanya mendorong bawahan untuk mencapai tujuan organisasi, tetapi akan memberikan kepuasan tersendiri bagi para individu dalam organisasi.

Simons (1990) menggolongkan peran alternatif ini sebagai peran 'interaktif'. Karakteristik pembeda fungsi interaktif ini adalah pertukaran informasi antara manajemen pusat dengan manajemen tingkat bawah secara kontinyu, serta interaksi antar fungsi-fungsi manajemen yang berbeda dalam satu tingkatan manajemen. Interaksi ini tidak hanya melibatkan partisipasi antara bawahan dengan atasan dalam proses pembuatan anggaran, tetapi juga dialog yang berkesinambungan antar anggota-anggota organisasi. Dalam seting seperti ini, sistem penganggaran menjadi 'markas data' yang menunjang proses pembelajaran organisasi. Penggunaan anggaran secara interaktif ini terjadi bila manajemen pusat menggunakan prosedur-prosedur perencanaan dan pengendalian untuk mengawasi dan terlibat secara aktif dengan bawahan dalam aktivitas-aktivitas pengambilan keputusan. Dengan keterlibatannya ini manajemen pusat dapat ikut mendebat dan menyanggah data-data, asumsiasumsi, dan rencana-rencana aktivitas. Dengan cara pengendalian manajemen interaktif seperti ini staff-staff operasional dari berbagai tingkatan 
organisasi didorong untuk memberikan perhatiannya.

Sebagai contoh dalam konteks perusahaan, CEO berfungsi sebagai agen utama perubahan strategis, jadi konsep teoretis yang relevan untuk cara penggunaan anggaran adalah gaya atau peran anggaran seperti yang dimaksudkan oleh CEO. Peran anggaran ini paling baik didefinisikan dalam kaitannya dengan persepsi CEO akan perilaku lahiriah spesifik mereka saat berinteraksi dengan pengguna strategi-strategi lain, disebut juga "peran yang diberlakukan" (Deutsch \& Krauss, 1965). Meski teori peran membedakan "peran yang diberlakukan" dari "peran yang diterima", namun penekanannya adalah bahwa perbedaan diantara keduanya memiliki dasar teoretis bukan sekedar merefleksikan kesalahan penilaian/penghitungan. Bahkan teori peran mendukung gagasan bahwa perilaku pengguna peranlah yang dipengaruhi langsung oleh konteks tertentu yang relevan. Dalam kasus ini, diupayakan untuk mengetahui bagaimana CEO merespon terhadap perubahan strategis, dan memprediksikan bahwa penerapan perubahan strategis yang efektif menciptakan peran tertentu bagi CEO dalam pengelolaan proses perubahan. Jadi disini yang lebih penting adalah persepsi CEO akan perilaku lahiriah atau peran mereka. Karena alasan inilah, penilaian gaya penggunaan anggaran dilandaskan pada peran CEO.

\section{Hubungan Penggunaan Anggaran dan Perubahan Strategis}

Literatur strategi menyebutkan bahwa perubahan teknologi dan produksi, atau pengembangan produk baru melahirkan rutinitas-rutinitas baru yang harus dipelajari lagi oleh perusahaan. Kondisi-kondisi ini memunculkan tuntutan-tuntutan ekstra bagi kapabilitas pengolahan informasi perusahaan (Galbraith 1977). Lebih lanjut Galbraith (1977) mengemukakan dalam penelitiannya bahwa agar perubahan strategis dapat menghasilkan peningkatan hasil-hasil organisasi dalam konteks keputusan ini, perusahaan perlu merespon kebutuhan-kebutuhan informasi ini dengan mengubah tatanan struktural dalam organisasi. Kapabilitas pengolahan informasi dapat ditingkatkan dengan menciptakan struktur organik yang lebih merata atau dengan menggunakan saranasarana penghubung seperti kesatuan tugas, tim-tim kerja, dan komitekomite inter-fungsionil. Untuk itu, peneliti ini menekankan perlunya dirancang suatu sistem yang dapat mendorong interaksi antara manajemen pusat dengan staff bawahannya untuk menunjang peningkatan arus informasi. Hal yang sama diungkapkan pula dalam penelitian yang dilakukan oleh Abernethy \& Lillis (1995), dan juga Mintzberg (1983). Mereka menyatakan bahwa sarana-sarana penghubung yang diciptakan untuk meningkatkan kapabilitas pengolahan informasi dirancang untuk menjembatani batasan-batasan fungsionil agar perusahaan menjadi lebih responsif, 
untuk meningkatkan kemampuan pemecahan masalah, dan menumbuhkan komunikasi lateral dan vertikal yang lebih informal. Lebih lanjut dalam penelitian tersebut diungkapkan bahwa karakteristik penting sarana penghubung adalah kemampuan mereka untuk menjembatani lini-lini pertanggungjawaban funsionil serta menjembatani antar tingkatantingkatan hirarkis.

Namun demikian, menurut Abernethy \& Lillis (1995), tatanan struktural ini kurang cocok disandingkan dengan pengendalian anggaran, yang dalam peran diagnostiknya merefleksikan struktur pertanggungjawaban tradisional Untuk dapat mengatur proses perubahan organisasi dengan efektif, manajemen pusat memerlukan informasi yang lebih prospektif. Mereka juga memerlukan proses pertukaran informasi yang interaktif dan dinamis. Oleh karena itu, dimensi interaktif ini menjadi semakin penting.

Abernethy dan Brownell
(1999) menguji peran penggunaan anggaran pada perusahaan yang mengalami perubahan strategis yang menjalankan bisnis dengan strategi yang berbeda, yaitu strategi bertahan (defender) dan strategi prospek (prospector). Hubungan tersebut ini dianalisis dengan menggunakan datadata dari 63 rumah sakit. Tipologi diagnostik interaktif Simons (1990; 1991) digunakan untuk menyelidiki peran penganggaran saat perusahaan sedang mengadakan perubahan strategis. Bukti-bukti yang ditemukan mendukung prediksi peneliti bahwa kinerja organisasi akan meningkat jika penganggaran digunakan secara interaktif pada saat organisasi sedang dalam proses reorientasi strategis. Berdasar penelitian tersebut, Abernethy dan Brownell (1999) menyimpulkan bahwa bila manajemen pusat menggunakan penganggaran secara interaktif, hal tersebut baik untuk memenuhi kebutuhan-kebutuhan pembelajaran dan adaptasi yang diperlukan bila organisasi sedang dalam proses perubahan strategis.

Hasil penelitian Abernethy dan Brownell (1999) tersebut konsisten dengan uraian Simons $(1990 ; 1991)$ tentang penggunaan sistem-sistem pengendalian dalam perusahaan yang sedang berusaha mengatasi ketidakpastian strategis. Bukti yang diperoleh mendukung pendapat Simons (1990) bahwa penerapan prioritas strategis yang efektif tidak selalu mempengaruhi peran penting pengendalian-pengendalian akuntansi, melainkan mempengaruhi cara-cara pemanfaatan pengendalianpengendalian tersebut. Lebih lanjut Simons (1991) mengungkapkan bahwa penggunaan anggaran secara interaktif dapat menjadi sarana bagi manajemen pusat untuk menyampaikan nilai-nilai dan preferensi mereka ke seluruh lapisan organisasi. Proses interaktif ini memungkinkan terjadinya pertukaran informasi mengenai peluang-peluang yang ada, ancaman-ancaman, keunggulan-keunggulan dan kelemahan-kelemahan organisasi pada saat berlangsungnya proses reorientasi pasar. Anggaran interaktif ini juga dapat menjadi sarana perdebatan untuk membahas cara-cara merespon 
perubahan situasi dan kondisi-kondisi operasional.

Penelitian lain, yaitu yang dilakukan oleh Macintosh (1994) dan Shields (1997) juga mengemukakan hal yang sama dengan penelitian yang dilakukan Simons (1991), yaitu bahwa anggaran dapat berfungsi sebagai penengah dari perdebatan sehingga membantu semua yang terlibat untuk mencapai kesepakatan daripada hanya memberikan suatu jawaban saja. Informasi variasi anggaran, misalnya, dapat digunakan sebagai sarana untuk mempelajari alternatif-alternatif lain beserta konsekuensi-konsekuensinya. Dengan cara ini anggaran memainkan peranan proaktif dalam menunjang penerapan perubahan strategis yang efektif.

Dukungan terhadap peran anggaran interaktif juga terdapat pada penelitian Hirst (1983). Hirst meneliti penggunaan sistem pembiayaan standar dan analisis varians yang sangat tergantung pada kestabilan proses-proses dan aktivitasaktivitasnya. Biaya-biaya standar memerlukan gambaran yang jelas akan hubungan input-output yang tidak bisa didapatkan bilamana perusahaan sedang mengalami perubahan, atau bila bentuk tugasnya sangat tidak menentu.

Dari berbagai penelitian tersebut secara tidak langsung memberlakukan anggaran sebagai suatu variabel yang mempengaruhi hubungan perubahan strategis dengan kinerja. Hubungan ini akan lebih positif bila anggaran digunakan secara interaktif dibandingkan bila anggaran digunakan secara diagnostik. Hal tersebut didasarkan pada efek perubahan strategis pada konteks keputusan. Proses perubahan menimbulkan konteks dimana pengambilan keputusan oleh manajemen pusat menjadi semakin kompleks dan tidak dapat diduga karena munculnya peluang-peluang baru atau prioritas-prioritas lain yang mengubah tujuan-tujuan strategis. Dalam situasi seperti ini, manajemen pusat seringkali harus menetapkan kembali target-target dan tujuantujuannya. Perubahan ini akan menimbulkan ketidakpastian atau ambiguitas bagi para bawahan mengenai prioritas atau preferensi apa yang harus mendapat perhatian utama.

Anggaran interaktif, dengan fokusnya pada dialog, komunikasi dan pembelajaran akan menjembatani hubungan antara manajemen pusat dengan staff bawahannya maupun antara manajer-manajer yang sama levelnya. Hal tersebut konsisten dengan pengoperasian kelompokkelompok penghubung lintasfungsionil. Bahkan anggaran interaktif itu sendiri dapat dipandang sebagai suatu sarana penghubung fungsionil yang menjembatani batasan-batasan hirarkis dan fungsionil yang menghambat arus informasi (Abernethy dan Brownell, 1999). Mempertahankan penggunaan anggaran secara diagnostik saat perusahaan sedang mengalami perubahan akan berdampak buruk bagi hubungan perubahan strategis dengan kinerja. Penggunaan diagnostik kurang mendukung komitmen anggotaanggota organisasi terhadap kelompok-kelompok penghubung 
antar-fungsionil, karena sistem penganggarannya justru semakin mengukuhkan lini-lini pertanggungjawaban dan kewenangan fungsionil yang ada. Jadi diperkirakan bahwa hubungan perubahan strategis dengan kinerja dapat ditingkatkan dengan menggunakan anggaran secara interaktif.

Namun demikian, penggunaan interaktif ini memerlukan keterlibatan esktensif manajemen pusat dalam proses penganggaran serta memerlukan interaksi yang erat diantara anggota-anggota organisasi. Oleh karena itu, penggunaan interaktif ini baru dapat meningkatkan kinerja organisasi bila perubahan strategisnya relatif tinggi. Maksudnya agar keuntungan penggunaan interaktif lebih besar dari pengorbanan yang dikeluarkan dalam situasi-situasi tersebut. Penggunaan diagnostik, di lain pihak, akan lebih efektif dalam situasi non-perubahan atau bila perubahannya minor. Dalam seting ini ambiguitas soal prioritas-prioritas organisasi tidaklah besar, dan bentuk kerjanya sendiri relatif stabil, dengan rutinitas-rutinitas tugas yang tetap dan sudah dipahami. Dalam situasi seperti ini anggaran merupakan sarana yang efektif untuk mengawasi dan mengontrol perilaku. Manajemen pusat dapat menggunakan laporan anggaran sebagai alat diagnostik untuk menilai hasil-hasil kerja dan memberikan penghargaan. Kekuatan utama pengendalian finansial, seperti anggaran, adalah kemampuannya untuk mengawasi proses-proses organisasional dengan handal dalam kondisi yang stabil.

Secara lebih jelas, dapat dikatakan bahwa hubungan antara tingkat perubahan strategis yang sedang berlangsung dengan kinerja organisasional dapat ditingkatkan dengan menggunakan anggaran secara interaktif. Sebaliknya, bila perusahaan tidak mengalami perubahan atau hanya sedikit perubahan, maka pengunaan anggaran secara diagnostiklah yang akan memberikan efek peningkatan kinerja. Dengan demikian maka perubahan strategis akan membawa hubungan yang positif dengan kinerja organisasi bila anggaran-anggarannya digunakan secara interaktif.

Hubungan antara penggunaan anggaran dan perubahan strategis yang menunjukkan fungsi penggunaan anggaran pada perusahaan yang mengalami perubahan strategis dapat digambarkan sebagai berikut:

Gambar 1 : Peran Penggunaan Anggaran dalam Perubahan Strategis

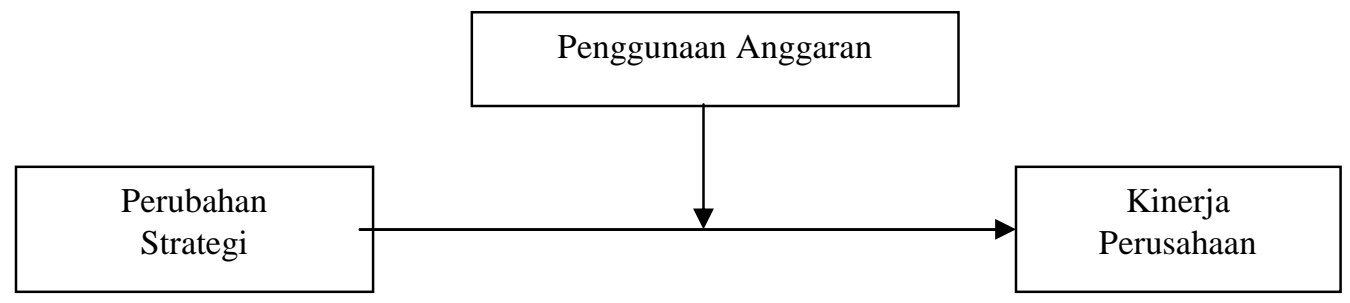




\section{KESIMPULAN}

Berdasar pada uraian yang telah dipaparkan diatas, dapat ditarik suatu kesimpulan sebagai berikut:

\section{Dalam literatur akuntansi} manajemen, dikenal adanya dua fungsi dari anggaran. Pertama adalah peran diagnostik. Dalam perannya ini, anggaran berfungsi sebagai pengevaluasi kinerja dan menghubungkan suatu hasil dengan fungsi atau anggota organisasi tertentu. Di sisi lain, anggaran juga berfungsi sebagai alat untuk mengkoordinasikan, mengkomunikasikan, memotivasi dan mengevaluasi prestasi. Peran ini disebut sebagai peran interaktif. Penggunaan anggaran secara interaktif ini terjadi bila manajemen pusat menggunakan prosedur-prosedur perencanaan dan pengendalian untuk mengawasi dan terlibat secara aktif dengan bawahan dalam aktivitasaktivitas pengambilan keputusan

2. Dalam perusahaan yang mengalami perubahan strategis relatif tinggi, maka penggunaan anggaran secara interaktif akan dapat meningkatkan kinerja organisasi. Hal tersebut dikarenakan penggunaan interaktif ini memerlukan keterlibatan esktensif manajemen pusat dalam proses penganggaran serta memerlukan interaksi yang erat diantara anggota-anggota organisasi tersebut.

3. Penggunaan diagnostik, di lain pihak, akan lebih efektif dalam situasi non-perubahan atau bila perubahannya minor. Dalam seting ini ambiguitas soal prioritasprioritas organisasi tidaklah besar, dan bentuk kerjanya sendiri relatif stabil, dengan rutinitas-rutinitas tugas yang tetap dan sudah dipahami. Dalam situasi seperti ini anggaran merupakan sarana yang efektif untuk mengawasi dan mengontrol perilaku.

\section{DAFTAR PUSTAKA}

Ansari, S.L 1977. An Integrated Approach to Control System Design, Accounting, Organization and Society, pp. 101-112.

Anthony, R.N. 1965. Planning and Control Systems: Framework for Analysis (Boston: Graduate School of Business Administration, Harvard University.

Bruns, W.J. \& Waterhouse, J.H. Auntumn, 1975. Budgetary Control and Organizational Structure, Journal of Accounting Research, pp. 177203.

Chong, K., Vincent. 1996. Management Accounting Systems, Task Uncertainty and Managerial Performance: A Research Note, Accounting, Organization and Society, pp. 415-421.

Cooper, D.R. \& C.W. Emory. 1995. Business Research Methods. $5^{\text {th }}$ Ed. USA: Irwin.

Fisher, G.J. 1988. Contingency Theory, management control systems and firm outcomes: Past results and future 
direction. Behavioral Research in Accounting, hal. 47-64.

Gordon, L.A. and V.K. Narayanan. 1984. Management Accounting System, Perceived Environmental Uncertainty and Organizational Structure: An Empirical Investigation, Accounting, Organization and Society, pp. 33-47.

Govindarajan, V. 1984. Appropriateness of accounting data in performance evaluation: an empirical examination of environmental uncertainty as an intervening variable. Accounting, Organizations and Society, 9(2), 125-135.

Govindarajan, V., \& A.K. Gupta. 1985. linking Control Systems to Business Unit Strategy: Impact on Performance. Accounting, Organization and Society, 10, 51-66, 125-135.

Gull, F. 1991. The effects of management accounting systems, environmental uncertainty on small business manager's performance. Accounting Organization and Society, hal. 57-61.

Gull, F. dan Y.M. Chia. 1994. The effect of management accounting systems, perceived environmental uncertainty and decentralization on managerial performance: A test of threeway interaction. Accounting Organization and Society.

Ittnerr, C.D. and D.F. Larcker. 1997. quality strategy, strategic control systems, and organizational performance.
Accounting Organizations and Society, Vol. 22, No. 3/4, pp. 293-314.

Kaplan, R. S. (ed.) 1990. Measures for Manufacturing Excellence. Boston, MA: Harvard Business Scholl Press.

Khandwalla, P.N. 1972. The effect of different type of competition on the use of management control. Journal of Accounting Research, hal. 275-285.

Macintosh, N.B. 1981. Contextual Model of Infortion System, Accounting, Organizations, and Society, pp. 39-55.

Margaret A. A \& P. Brownell. 1999. The Role of Budgets in Organizations Facing Strategic Change: An Exploratory Study, Accounting, Organizations and Society 24, pp 189-204.

Mia, I. 1993. The Role of Management Accounting Systems Information in Organization: An Empirical Study, British Accounting Review, pp. 269285.

Mia, I. dan R. H. Chenhall. 1994. The usefulness of management accounting systems, functional differentiatio and managerial effectiveness. Accounting Organization and Society, hal. 1-13.

Miller, D. dan P.H. Friesen. 1986. Porter's generic strategies and performance. Organization Studies, 7, hal. 35-55.

Miles, R.W., \& C.C. Snow. 1978. organizational strategy, Structure, and Process. McGraw-Hill, New York. 
Miller, D. \& P.H. Friesen. 1982. innovation in concervative and entrepreneurial firm: two models of strategic momentum. Strategic Management Journal. Pp. 1-25.

Mintzberg, H. 1973. Strategy making in three models. California Management Review, hal. 4453.

Mulyadi. 2000. Balanced Scorecard. Universitas Gadjah Mada, Yogyakarta.

Porter, M.E. 1980. Competitive Advantage. The Free Press, New York.

Porter, M.E. 1985. Competitive Advantage. The Free Press, New York.

Simons, R. 1987. accounting control systems and business strategy: An empirical analysis. Accounting, Organizations and Society. Vol. 12, No. 4. pp. 357-372.
Simons, R. 1990. The role of management control systems in creating competitive advantage: New perspective. Accounting Organizations and Society, hal. 127-143.

Smith, K.L. 1997. management control system and strategy: A critical review. Accounting Organization and Society, Vol. 22. No. 2, pp. 207-232.

Suryani, E. 2001. Analysis hubungan antara strategi kualitas, system pengendalian strategic dan kinerja organisasional: studi empiris pada kondisi krisis di Indonesia. Tesis S-2. UGM. Yogyakarta.

Van de Ven, A. H. dan R. Drazin. 1985. The concept of fit in contingency theory. Research in Organizational Behavior, 7. 